VIGNETTE

\title{
Some Reflections on Disciplines and Curricula
}

\author{
LIXIN LUO \\ University of Alberta, (Canada)
}

I have taught math at several Canadian high schools for four years. At the beginning of my career, I mainly taught academic Grade 12 math students who have reasonable math backgrounds and who are interested in university education. Although I did learn classroom management skills over time by teaching this type of class, I spent most of my time improving my class delivery and evaluations. By the time I started to teach a Grade 11 college math course, I was very confident in my lesson design and delivery skills, and I believed my students would learn some "good" math from my classes. I was wrong.

My two Grade 11 college math classes were very small (average 15 students in each class), but the students were more troublesome than any classes I had taught before. Nevertheless, I managed to get most of the students to try to listen to my instructions during each class section. No matter how reluctant they were to learn in class, the majority of students usually would try to practice and they seemed to comprehend the material in class. But often when I asked them the same question in the next class, most students could not answer it. I quickly found myself re-teaching the same thing again and again in different ways. Yes, the fact that I might not have used the most effective methods to teach all the time and that the students rarely did homework did count. But I believed there had to be some other reasons.

The Grade 11 college math course itself is easy. If you can solve one-variable equations, deal with ratios, and apply a formula, you can survive this course easily. However, many of my students were not capable of doing some or all of these types of problems. Some students had only elementary level math skills and the difference between different students' math levels was huge. Whole class teaching did not work well with this group. These students needed lots of individual help. For some, even individual help in every class was not sufficient; they needed more time and attention, which I did not have within the current educational setting. I wished they did not have to attend class all at the same time, and that they could study at their own pace. 
Besides the readiness problem, there was the interest problem. Only one out of these 30 students showed even a slight interest in math, while the rest of them appeared indifferent to math. Most of them could not see how math related to their lives. Many of them took this course to fulfill the requirement of three compulsory math credits and they said "no math forever" after this course. To keep so many students who disliked math and who did not have the prerequisite math skills in class and to motivate them to learn is the most frustrating experience I had ever had.

I tried to connect math with their real world. When I was teaching the quadratic function chapter, I started with a real-life business scenario in which one needs to find out the optimal price to sell a T-shirt. One student with very low math skills said she liked this way of teaching, as she finally understood what was going on. I was very pleased. But soon the course curriculum required the students learn how to factor a quadratic expression in order to find the zeros of a quadratic function later. Here I totally lost her and many other students. They could not understand why they needed to learn this and had a hard time dealing with math symbols. They suffered so much in this unit that they totally lost their initial interest. I could not help but doubt the value of teaching this kind of knowledge to them.

Obviously this group of students learns best when they see how what they learn is connected to their real world; whenever I taught math problems within some real life scenarios, they were more motivated and engaged. Why do they have to learn something preset in the curriculum that has no obvious value and interest to them? What is the point of teaching math alone to them when they can more readily understand things in a holistic way? Rather than forcing them all to sit in a class to learn math isolated from other subjects, would it not be better to have them learn how to solve some real-life problems and learn whatever math is needed along the way?

I believe the fact that many of my students managed to pass the previous math courses and ended up sitting in my class with blank faces is largely due to the use of "cheat sheets". Everyone in my school knows that applied level math students are allowed to use a cheat sheet during quizzes, tests, and even final exams. With these "aids", you still see students passing the term with strong grades and ending up failing the final exam when they are asked questions based on the whole course. They pass the courses, though, as the final exam is only $30 \%$ of the final mark. So they never learn anything well enough except copying and matching, as a couple of my students told me. When I banned cheat sheets from my classes at the beginning of the course, even though my students complained about it, they went along with my decision. They knew what was good for them and wanted to try. But I had to do much more to help them pass this course.

What I see from my students is that even if they want to learn, they do not know how to, or they do not have enough basic math skills. They had been trained to rely on cheat sheets since Grade 9. This cheat sheets policy sounds foolish as it totally defeats the purpose of education, but it is the last resort the teachers at my school (and other schools) use to save their "miserable" teaching year with this group of students.

Thanks to the cheat sheets policy, after sitting through and passing the Grade 9 and Grade 10 applied level math courses, students may take a Grade 11 college focused math course. Many Grade 11 students, however, really belong with applied level math students, who unfortunately have a reputation of being weak and disinterested in math (and/or many other subjects) and not knowing how to learn and behave in class. It is well known that classroom management is the biggest issue in any applied level math class. You can have so many classroom management problems in one applied class that the only thing you want to do in the class is to get by without teaching. Nobody in my department likes to teach applied level math students. Why do we have so many discipline problems in the applied math class? Can we not see that the use of cheat sheets already tell us how problematic this education system is? 
The more I think about my struggles while teaching high school students, the more I realize the education system is problematic. All the regular schools have a preset curriculum for students to take. Students are trained to fit into the current structure in order to earn more freedom in the future. They are told to study something they are totally uninterested in just because they have to.

One might argue that students might choose these courses themselves. But these choices are not authentic. In general, most students do not want to choose lower level math courses because that will may them look stupid. So, even students who do not really need college level math to graduate and/or who suffered in previous math courses in Grade 10 tend to choose Grade 11 college math.

For those interested in college education, they think taking Grade 9 and Grade 10 applied math and passing a Grade 11 college math course will help them get into college. They do not know this path is poorly designed (especially with the "help" of cheat sheets); thus by the time they are in Grade 11, they are not ready for a real Grade 11 college math course and do not realize that what they will get from a not-real Grade 11 college math course is far less than they will need for a college program.

A real choice, according to Nel Noddings (2007), should be well informed and not simply based on students' past school performance. Non-academic tracks should be made rich and attractive so that students can choose any course offered by the school. Without an education system that cherishes real choices and truly promotes diversity, we end up having many reluctant learners in one class, which causes discipline problems and wastes class time. By the time the students have finished their study at school, they also have lost their creativity and interest for learning.

This same problem exists in the universities. Many programs offered in the universities exist due to the demand of the job market. Students normally follow an existing program to become certain types of workers or to get certain types of jobs. The curriculum in universities is largely preset too. This kind of curriculum makes schools more like factories, as understood by Franklin Bobbitt, in which the number one principle of management is "definite qualitative and quantitative standards must be determined for the product" (Bobbitt, quoted in Callahan, 1962, p. 81).

I believe the university (and the school, too) should be a place where one can express creativity and choice. Why do we think educators know what is best for the students? Is it largely due to efficiency that in curriculum we focus on what we adults want the students to know rather than on what the students really want to learn? Why cannot a student study whatever subjects s/ he wants and become a person without one discipline but with multi-disciplines? Why do we have to divide learning contents into exclusive subjects and disciplines?

Frank Moss believes one key factor that contributes to the creativity and innovation of the MIT Media Lab is its anti-disciplinary research style. Moss (2011) understands that as real-life problems become more and more complex and multidimensional, often you cannot simply label a problem as a biology discipline problem with which a biology expert can deal. Solutions can only be found when people abandon the boundaries between so-called discrete disciplines. So, in the MIT Media Lab, people with all types of backgrounds work together. For example, a person with an anthropology degree works with a person with a computer science background to deal with a rare disease. Even though they do not have medical backgrounds, they come up with new approaches, as they have to think differently. Moss (2011) elaborates his thought clearly in the following:

Since joining the Media Lab, I've come to believe strongly that the key to coming up with game-changing innovation lies not in finding novel solutions to known questions but, rather, in positing novel questions. Only by ignoring the existing artificially imposed barriers between disciplines can we 'completely change the frame' of the discussion and 
pose questions that no one has ever thought to ask before, including - maybe even especially - the so-called domain experts. (p.40)

Over the years, through my teaching, I see more clearly the need for breaking the boundaries between the subjects at school. When we set up a clear boundary between disciplines, we teach students a simplified version of the world. Students are not taught how to deal with complex problems, which cannot be categorized into any single discipline. When we set up the same curriculum for all students, combining this with the power of marks, we trap our students in a limited box of possibilities. My personal experience of being a student in a Master's Program for Math Teachers at the university level has warned me, again, of this danger. I see myself working hard to get full marks (which I did get) without putting more effort to learn extra content (thinking that I would learn this material later). Due to this curricular focus, I can differentiate between what is needed for marks and what appears "extraneous". Thus, I am limited. The education system I had gone through still has a strong influence on how I study. If there had been no preset curriculum then there may have been no external standard to limit my imagination, and then no limitation on whom I could become.

From my point of view, a school should be full of labs and experiences with real and complex problems. Students should be free to join whichever lab or academic experience that interests them. They could then learn whatever knowledge is needed to solve problems or study one problem in some depth, regardless of the disciplines into which the knowledge is categorized.

I am not saying that we must change all existing schools (which is too much to ask at one time). I am saying that we should have more alternative schools without an arbitrary preset curriculum and without a separation between disciplines, more schools that adapt to students rather than having students adapt to the schools, and more schools that put learners in the control position of their learning and allow them to be creative.

\title{
References
}

Callahan, R.E. (1962). Education and the cult of efficiency. Chicago: Chicago University Press.

Moss, F. (2011). The sorcerers and their apprentices: How the digital magicians of the MIT Media Lab are creating the innovative technologies that will transform our lives. New York: Crown Business.

Noddings, N. (2007). When school reform goes wrong. New York: Teachers College Press.

\begin{abstract}
About the Author
Lixin Luo has been admitted to the Ph.D. program in Secondary Education at the University of Alberta. Her program starts in September 2012. She is a former mathematics and computer science teacher in Toronto. She explores teaching and learning through the lens of complexity theory.
\end{abstract}

(c) Copyright 2012. The author, LIXIN LUO, assigns to the University of Alberta and other educational and non-profit institutions a non-exclusive license to use this document for personal use and in courses of instruction provided that the article is used in full and this copyright statement is reproduced. The author also grants a non-exclusive license to the University of Alberta to publish this document in full on the World Wide Web, and for the document to be published on mirrors on the World Wide Web. Any other usage is prohibited without the express permission of the author. 